\title{
Managing a Country's Sustainabilty - The Case of Malaysia and Indonesia Public Debt
}

\author{
Abdul Razak Abdul Hadi ${ }^{1}$, Tasya Aspiranti ${ }^{2}$, Tahir Iqbal ${ }^{1} \&$ Raja Rehan $^{1}$ \\ ${ }^{1}$ University Kuala Lumpur Business School, Kuala Lumpur, Malaysia \\ ${ }^{2}$ Universitas Islam Bandung, Indonesia \\ Correspondence: Abdul Razak Abdul Hadi, University Kuala Lumpur Business School, Kuala Lumpur, Malaysia.
}

Received: April 30, 2019

doi:10.5430/ijfr.v10n5p19
Accepted: May 30, 2019

Online Published: June 10, 2019

URL: https://doi.org/10.5430/ijfr.v10n5p19

\begin{abstract}
The study is driven by the motivation to examine the effects of policy interest rates and crude oil prices on Malaysian and Indonesian government borrowing within the framework of Keynesian macroeconomic theory. Using Autoregressive Distributed Lag (ARDL) model as an estimation tool over the observed period from March 2013 till June 2018, the study uncovers the absence of long-term equilibrium relationship between government borrowings and the two explanatory variables. However, based upon Error Correction Representation via ARDL model, there is a significant long-run relation (at 10\% level) between Indonesian government borrowing and the two tested variables. Interestingly, this is not the case for Malaysia over both long-run and short-run relations. With respect to the short-run dynamics, there is a unidirectional causality running from crude oil price to Indonesian government borrowing. It seems crude oil price plays a significant role in influencing Indonesian government's choice of public financing. As expected, the short-term policy rate has no significant bearing on government borrowings at all.
\end{abstract}

Keywords: Malaysian government borrowings, Indonesia public debt, autoregressive distributed lag cointegration, West Texas intermediate price and policy interest rates

\section{Introduction}

Malaysia and Indonesia are both oil-producing countries and it is intriguing to investigate to what extent that changes in crude oil price over the past five years could affect the government's choice of financing. The fluctuation in crude oil price has caused many oil-producing countries, particularly the governments to review their fiscal and monetary policy. The Asian Debt Crisis 1997 has been a very good example on how Malaysia and Indonesia managed their public debts. The world has witnessed how Malaysia refused to subscribe the prescription given by International Monetary Fund (IMF) and decided to peg its Ringgit Malaysia (RM) to USD, coupled with massive domestic government borrowing. Meanwhile, Indonesia agreed to follow the rescue plan organized by IMF and indulged in foreign borrowing. As a result, the Indonesia domestic interest rate increased sharply and forced many companies into insolvencies due to their inability to repay short-term debts and term loans. The sudden change in the monetary policy (as shown by sharp increase in the interest rates) detrimentally affected all market players in the Indonesia economy. This study is pursued with the motivation to find out the relationships between these three variables and government borrowing is the variable of interest. The crude oil price has started to decline since September 2014 and it reached the bottom of USD37 per barrel in March 2016. Such a price swing would detrimentally affect government revenue, which in turn triggers the need for government borrowing. This study is narrowed towards a number of pertinent issues within the expansionary fiscal policy as well as monetary policy.

Hashemzadeh \& Taylor (1988) examine the causality between stock prices, money supply and interest rates. From the Granger-Sims test, they find that rise interest rates reduce the present value of future cash flows to be received by the investors or lenders. In addition, the causality seems to be mostly running from the interest rates to stock prices. They also disclose that there is a strong empirical linkage between money supply and stock prices and between stock prices and market interest rates. Further many studies also find similar results, like Le (2015); Sweis \& Sabri (2016); Owusu-Antwi, et.al., (2017); Forgha, et.al., (2018); Aremu (2018); Onyinye, Jonathan \& Emmanuel (2018).

Pierson (1968) concludes that monetary policy affects all rates, with greatest effect on short-term rates. Fama \& Schwert (1977) found a statistically significant negative relationship between stock returns and future interest rate 
changes. Based on the high correlation, they suggest the inclusion of the stock price movement in the inflation forecasting models. It is important to note that inflationary premium is one of the important factors that determine the prevailing market interest rate (Haseeb, Abidin, Hye \& Hartani, 2018; Sanusi et al., 2017; Özmaden, Soter \& Özmaden 2018).

Literature suggests that some governments may prefer external borrowing in foreign currency so as to mitigate the crowding-out effect. Crowding-out effect is an economic phenomenon that stem from government borrowing (Mahmoud et al., 2013). An increase in government spending or a decrease in tax revenue would lead to a budget deficit that is later financed by increased government borrowing. Such a borrowing will increase demand for money and consequently pushes interest rate upward. The net effect is a reduction in private investment. Nguyen (2018) asserts that there are positive growth effects of fiscal policy across emerging markets and the study also finds interesting evidences that the external debt has non-linear effects on economic growth. Having discussed the importance of public finance and its impacts on economic growth, the following research questions are studied and analysed: Did the fluctuation in crude oil price influence government borrowing? What is the causality relationship between policy interest rate and government borrowing?

\section{Data \& Methodology}

This study attempts to reveal the theoretical link between government borrowing and two explanatory variables policy interest rate and crude oil price. Since both Malaysia and Indonesia are oil-producing countries, the tax collections from the oil and gas industry has been a worthy source of revenue for the governments. As such, changes in crude oil price are likely to influence the government's fiscal policy. The crude oil price is proxied by West Texas Intermediate (WTI) whilst overnight policy rate (OPR) and bank interest rate (BIR) represent the policy rate for Malaysia and Indonesia respectively. The study uses quarterly secondary data spanning from March 2013 through June 2018, involving 22 data points. All economic data are obtained from Bank Negara Malaysia Statistical Bulletin and Indonesia Ministry of Finance. It is important to note that both OPR and BIR are short-term intervention rate set by the central banks - Bank Negara Malaysia and Bank Indonesia respectively.

\subsection{Empirical Model}

The empirical model is based upon expansionary fiscal policy and specifically formulated as follows:

$$
\mathrm{GB}_{\mathrm{t}}=\mathrm{a}-\beta 1 \mathrm{WTI}_{\mathrm{t}}-\beta 2 \mathrm{IR}_{\mathrm{t}}+\varepsilon_{\mathrm{t}}
$$

Where:

$\mathrm{GB}=$ Government Borrowing

$\mathrm{a}=$ intercept

$\mathrm{WTI}=$ Crude Oil Price

IR $=$ Short-term Policy Interest Rate

$\varepsilon_{t}=$ Error Terms

From the empirical model, the study stipulates negative relationship between government borrowing and the two explanatory variables. An increase in crude oil price will generate incremental revenue for the government and therefore reduce the level of government borrowing. Similarly, an increase in the level of interest rate will push borrowing cost upward and therefore reduce the level of government borrowing. It is somehow still debatable as to whether the current level of market interest rate is likely to influence government's decision to increase borrowing. Technically, the policy interest rate specification in this empirical model contradicts the conventional theory of money supply.

The movements OPR and BIR are compared over the study period and presented in Figure 1 below. It is evident that the BIR is relatively higher and more erratic than the OPR. The high level of interest rate in Indonesia is attributed to the Asian Debt Crisis 1997 and the trend continues till today. 


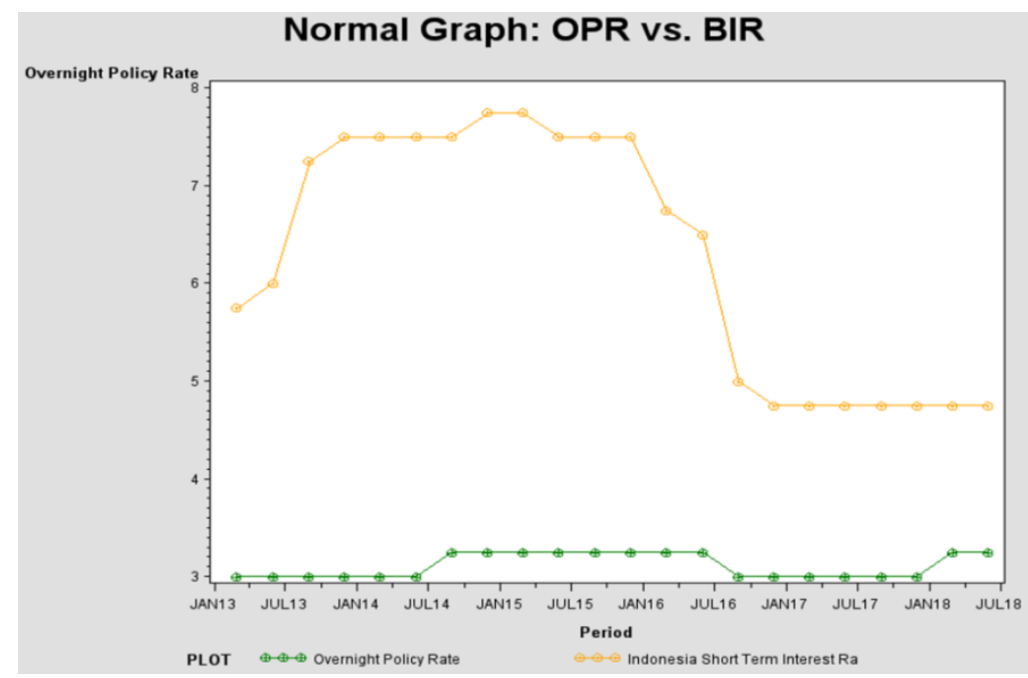

Figure 1. Movements of OPR versus BIR

In investigating the lead-lag relationship in the empirical model, the Autoregressive Distributed Lag (ARDL) bounds-testing methodology is deployed (Pesaran and Shin, 1999). This estimation method is selected due to its unique strength as compared to other conventional method like Engle and Granger (1987). Having 22 data points, ARDL is deemed as the best estimation tool. In addition, the ARDL approach examines the long-run equilibrium relationship between the variables regardless of whether the explanatory variables are characterized by $\mathrm{I}(0)$, I(1) or partially integrated (Pesaran et al., 2000; Patnaik \& Pillai 2017). One unique feature about ARDL model is its capability in handling limited sample size and yet it delivers robust results in relation to the cointegration analysis (Paseran et al., 2000; Ali, Mahmoud \& Mahmoud 2016).

To carry out the cointegration analysis via ARDL model, the following ARDL [p, q, r] equation is specified:

$$
\begin{aligned}
\Delta \mathrm{GB}_{\mathrm{t}} & =\alpha_{\mathrm{GB}}+\sum_{\mathrm{I}=1}^{\mathrm{P}} \lambda_{\mathrm{iGB}} \Delta \mathrm{GB}_{\mathrm{t}-\mathrm{i}}+\sum_{\mathrm{j}=1}^{\mathrm{q}} \lambda_{\mathrm{jGB}} \Delta \mathrm{WTI}_{\mathrm{t}-\mathrm{j}}+\sum_{\mathrm{k}=1}^{\mathrm{r}} \lambda_{\mathrm{kGB}} \Delta \mathrm{IR}_{\mathrm{t}-\mathrm{k}}+\delta_{1 \mathrm{~GB}} \mathrm{~GB}_{\mathrm{t}-1} \\
& +\delta_{2 \mathrm{~GB}} \mathrm{WTI}_{\mathrm{t}-1}+\delta_{3 \mathrm{~GB}} \mathrm{IR}_{\mathrm{t}-1}+\mathrm{c}_{\mathrm{t}}
\end{aligned}
$$

Specifically, $\Delta$ indicates change; $\alpha_{G B}$ denotes the intercept; $\varsigma_{t}$ represents the white noise; $\lambda$ is the short-run coefficient and $\delta$ is the corresponding long-term multiplier of the underlying ARDL model. The null hypothesis of no cointegration is tested by using the general F-statistics. Should the computed F-statistics be greater than the value of the upper bound, the null hypothesis is therefore rejected implying the presence of long-run relationship between the tested variables (Alkali \& Imam 2016).

\section{Empirical Findings}

To begin with, the correlation matrix among all the variables is presented in Table 1. In the case of Malaysia, the WTI is moderately correlated with the government total debt. Similar finding is also observed in the Indonesian scenario. Both government borrowings and WTI are negatively correlated. With respect to the short-term policy rate, there is a high negative correlation between Indonesian external debt and BIR. In contrast, weak correlation is seen between OPR and Malaysia government borrowing.

Table 1. Pearson correlation analysis

Pearson Correlation Coefficients, $\mathrm{N}=22$

Prob $>|\mathrm{r}|$ under H0: Rho $=0$

\begin{tabular}{llllll}
\hline & FedDebt & OPR & WTI & ExtDebt & BIR \\
\hline FedDebt & 1.00000 & 0.24788 & -0.67355 & -0.67355 & -0.63820 \\
\cline { 2 - 6 } Malaysia Federal Debt in RM mill & & $(0.2660)$ & $(0.0006)$ & $(0.0006)$ & $(0.0014)$ \\
\hline OPR & 0.24788 & 1.00000 & -0.42768 & 0.07136 & 0.38698 \\
Malaysia Overnight Policy Rate & $(0.2660)$ & & $(0.0471)$ & $(0.7523)$ & $(0.0752)$ \\
\hline
\end{tabular}




\begin{tabular}{llllll}
\hline WTI & -0.67355 & -0.42768 & 1.00000 & -0.59691 & 0.24266 \\
\cline { 2 - 6 } West Texas Intermediate in USD/Barrel & $(0.0006)$ & $(0.0471)$ & & $(0.0034)$ & $(0.2766)$ \\
\hline ExtDebt & 0.95543 & 0.07136 & -0.59691 & 1.00000 & -0.78540 \\
\cline { 2 - 6 } Indonesia Federal External Debt in USD mill & $(<.0001)$ & $(0.7523)$ & $(0.0034)$ & & $(<.0001)$ \\
\hline BIR & -0.63820 & 0.38698 & 0.24266 & -0.78540 & 1.00000 \\
\cline { 2 - 6 } Indonesia Short Term Interest Rate & $(0.0014)$ & $(0.0752)$ & $(0.2766)$ & $(<.0001)$ & \\
\hline
\end{tabular}

Table 2 shows the results from the ARDL estimation model and hypothesis testing is carried out to determine the presence of long-run equilibrium relationship. From the value of F-Statistic, the null hypothesis of no cointegration cannot be rejected as it stands lower than the upper-bound critical value of 5.8099. However, based upon Error Correction Representation via ARDL model in Table 3, there is a significant long-run relationship (at 10\% level) between Indonesian government external borrowing and the two tested variables (Hussain et al., 2019). Furthermore, the presence of short-term dynamic relationship between WTI and government borrowing is also observed in this model.

Table 2. Optimum lag-length and ARDLbounds-testing approach (Indonesia)

\begin{tabular}{llll}
\hline \multicolumn{4}{l}{ Autoregressive Distributed Lag Estimates } \\
\hline \multicolumn{4}{l}{ ARDL $(1,0,0)$} \\
\hline \multicolumn{4}{l}{ Depelected based on Akaike Information Criterion } \\
\hline Regressor & Coefficient & Std Error & T-Ratio (Prob) \\
\hline IFED(-1) & 0.776 & 0.127 & $6.067(0.000)$ \\
\hline IBIR & -2472.400 & 1874.900 & $-1.318(0.205)$ \\
\hline COWTI & -130.610 & 61.741 & $-2.106(0.050)$ \\
\hline R-Squared & 0.946 & Adj R-Squared & 0.936 \\
\hline
\end{tabular}

\begin{tabular}{lllll}
\hline \multicolumn{5}{l}{ Testing for existence of a level relationship among the variables in the ARDL Model } \\
\hline F-Statistic & 95\% Lower Bound & 95\% Upper Bound & 90\% Lower Bound & 90\% Upper Bound \\
\hline 1.8110 & 4.5123 & 5.8099 & 3.6370 & 4.6435 \\
\hline
\end{tabular}

Table 3. Error correction representation for the selected ARDL model

\begin{tabular}{llll}
\hline \multicolumn{4}{l}{ ARDL $(1,0,0)$} \\
\hline \multicolumn{4}{l}{ Dependected bariable: dIFED } \\
\hline Regressor & Coefficient & Std Error & T-Ratio (Prob) \\
\hline dIBIR & -2472.400 & 1874.900 & $-1.318(0.205)$ \\
\hline dCOWTI & -130.050 & 61.741 & $-2.105(0.05)$ \\
\hline ecm $(-1)$ & -0.224 & 0.127 & $-1.752(0.098)$ \\
\hline R-Squared & 0.229 & Adj R-Squared & 0.093 \\
\hline R-Squared \& Adj R-Squared measures refer to the dependent variable \\
\hline
\end{tabular}

In the case of Malaysia, there is no significant long-term and short-term relationship that can be established between the tested variables. From the ARDL bounds-testing in Table 4, the computed F-Statistic is very much lower than the upper-bound critical value. Similarly, the test results from the Error Correction Model in Table 5 do not provide much insight to the tested model (Ametorwo, 2016). Both WTI and short-term policy rate do not hold any statistically significant bearing on Malaysia government borrowing. 
Table 4. Optimum lag-length and ARDL bounds-testing approach (Malaysia)

\begin{tabular}{|c|c|c|c|}
\hline \multicolumn{4}{|c|}{ Autoregressive Distributed Lag Estimates } \\
\hline \multicolumn{4}{|c|}{ ARDL $(1,0,1)$ selected based on Akaike Information Criterion } \\
\hline \multicolumn{4}{|c|}{ Dependent variable: Malaysia Federal Debt (MFD) } \\
\hline Regressor & Coefficient & Std Error & T-Ratio (Prob) \\
\hline $\operatorname{MFD}(-1)$ & 0.962 & 0.0628 & $15.313(0.000)$ \\
\hline MOPR & 32375.4 & 21572.4 & $1.5008(0.153)$ \\
\hline COWTI & 425.635 & 248.73 & $1.7112(0.106)$ \\
\hline COWTI (-1) & -384.733 & 257.77 & $-1.4925(0.155)$ \\
\hline R-Squared & 0.973 & Adj R-Squared & 0.966 \\
\hline
\end{tabular}

Testing for existence of a level relationship among the variables in the ARDL Model

\begin{tabular}{lllll}
\hline F-Statistic & $95 \%$ Lower Bound & $95 \%$ Upper Bound & $90 \%$ Lower Bound & $90 \%$ Upper Bound \\
\hline 0.2600 & 4.5123 & 5.8099 & 3.6370 & 4.6435 \\
\hline
\end{tabular}

Table 5. Error correction representation for the selected ARDL model

\begin{tabular}{llll}
\hline \multicolumn{4}{l}{ ARDL(1,0,1) selected based on Akaike Information Criterion } \\
\hline \multicolumn{4}{l}{ Dependent variable: dMFD } \\
\hline Regressor & Coefficient & Std Error & T-Ratio (Prob) \\
\hline dMOPR & 32375.4 & 21572.4 & $1.5008(0.152)$ \\
\hline dCOWTI & 425.635 & 248.735 & $1.7112(0.105)$ \\
\hline ecm(-1) & -0.037 & 0.062 & $-0.595(0.560)$ \\
\hline R-Squared & 0.2042 & Adj R-Squared & 0.0053 \\
\hline \multicolumn{4}{l}{ R-Squared \& Adj R-Squared measures refer to the dependent variable } \\
\hline
\end{tabular}

The study addresses the issue of crowding-out effect by examining the effect of government borrowing on the level of interest rate. The results from ARDL bounds-testing do not support the presence of long-run equilibrium relationship between Malaysia short-term policy rate and government borrowing. Nevertheless, the Error Correction model delivers some interesting insight whereby the value of error correction term support the presence of long term relationship (at $10 \%$ level of significance) with almost $20 \%$ speed of adjustment towards equilibrium. There is also a significant short-term relationship between Malaysia government borrowing and the short-term policy rate. This suggests a short-run causality running from Malaysia government borrowing to OPR. To ensure the credibility of the estimated model, diagnostic tests are performed and reported. Overall, there is no major shortcoming in these ARDL models (Önder, 2018).

Table 6. Optimum lag-length and ARDL bounds-testing approach (Malaysia)

\begin{tabular}{llll}
\hline \multicolumn{4}{l}{ Autoregressive Distributed Lag Estimates } \\
\hline \multicolumn{4}{l}{ ARDL(1,0,1) } \\
\hline \multicolumn{4}{l}{ Delected based on Akaike Information Criterion } \\
\hline Regressor & Coefficient & Std Error & T-Ratio (Prob) \\
\hline MOPR(-1) & 0.8111 & 0.0915 & $8.8618(0.000)$ \\
\hline COWTI & -0.0013 & 0.0019 & $-0 . .6687(0.513)$ \\
\hline COWTI (-1) & 0.0031 & 0.0020 & $1.5223(0.146)$ \\
\hline MFD & $0.7617 \mathrm{E}-6$ & $0.4044 \mathrm{E}-6$ & $1.8837(0.077)$ \\
\hline R-Squared & 0.5744 & Adj R-Squared & 0.4993 \\
\hline
\end{tabular}




\begin{tabular}{lllll}
\hline \multicolumn{5}{l}{ Testing for existence of a level relationship among the variables in the ARDL Model } \\
\hline F-Statistic & $95 \%$ Lower Bound & $95 \%$ Upper Bound & 90\% Lower Bound & $90 \%$ Upper Bound \\
\hline 1.4461 & 3.1746 & 4.4340 & 2.4443 & 3.5057 \\
\hline
\end{tabular}

Table 7. Error correction representation for the selected ARDL model

\begin{tabular}{llll}
\hline \multicolumn{4}{l}{ ARDL(1,0,1) selected based on Akaike Information Criterion } \\
\hline \multicolumn{4}{l}{ Dependent variable: dMOPR } \\
\hline Regressor & Coefficient & Std Error & T-Ratio (Prob) \\
\hline dCOWTI & -0.0013 & 0.0019 & $-0.6687(0.512)$ \\
\hline dMFD & $0.7617 \mathrm{E}-6$ & $0.4044 \mathrm{E}-6$ & $1.8837(0.076)$ \\
\hline ecm(-1) & -0.1888 & 0.0915 & $-2.0632(0.054)$ \\
\hline R-Squared & 0.2449 & Adj R-Squared & 0.1116 \\
\hline R-Squared \& Adj R-Squared measures refer to the dependent variable
\end{tabular}

It is important to understand the economic implications from expansionary fiscal policy via government borrowing. The choice is either the government opts for domestic or foreign currency borrowing. About $75 \%$ of Malaysia federal debt is dominated in RM and any increase in government borrowing would trigger upward pressure on the level of interest rate. Such a development will definitely lead to the phenomenon of crowding out effect in the domestic money market (Altıntaş \& Yacouba 2017; Ozkurt \& Alpay 2018). With regard to policy implication, this study has clearly shown that any domestic borrowing by a government will result in the undesirable economic situation, that is, the crowding-out effect. As such, dealing with a foreign borrowing is viewed as the best option to ward off this detrimental effect. That was the prescription given by IMF to Indonesia during the Asian Debt Crisis 1997. At present, Malaysian government is negotiating with a Japanese bank in rising external financing to rejuvenate the domestic economic activities.

\section{Conclusion}

From the results of ARDL model, the study uncovers absence of long-term equilibrium relationship between government borrowings and the two explanatory variables. However, based upon Error Correction Representation via ARDL model, there is a significant long-run relation (at 10\% level) between Indonesian government borrowing and the two tested variables. Ironically, this is not the case for Malaysia on both long-run and short-run relations. With respect to the short-run dynamics, there is a unidirectional causality running from crude oil price to Indonesian government borrowing. It appears that crude oil price plays a significant role in influencing Indonesian government's choice of public financing. As expected, the government borrowing in both countries are not influenced by the short-term policy rates at all. This finding is consistent with the Monetarist criticism that expansionary fiscal policy through increase in government borrowing would eventually lead to increase in the level of interest rate. As a whole, this study provides one imperative perspective for policy makers. The crowding-out effect is a domestic phenomenon, which is attributable to the domestic borrowing undertaken by a government.

\section{References}

Ali, B., Mahmoud, O., \& Mahmoud, Y. (2016). Studying the Integration of Damascus Securities Exchange with Selected Stock Markets. International Journal of Business, Economics and Management, 3(7), 85-102.

Alkali, M. Y., \& Imam, M. I. (2016). Accountability and environmental sustainability: Nigerian maritime experience. Asian Journal of Economics and Empirical Research, 3(1), 1-5.

Altıntaş, H., \& Yacouba, K. (2017). A Multivariate Causality Analysis of Economic Growth and Electricity Consumption in Turkey. Energy Economics Letters, 4(2), 9-19.

Ametorwo, A. M. (2016). Managing Work Family Conflict among Female Entrepreneurs in Ghana for Development. International Journal of Economics, Business and Management Studies, 3(1), 21-35.

Aremu, J. O. (2018). A Historical Analysis of the Nature, Causes and Impact of the Foreign Debt Crisis in Latin America, 1970- 1980. Humanities and Social Sciences Letters, 6(3), 74-83. 
Engle R. F., \& Granger, C. W. J. (1987). Co-integration and Error Correction: Representation, Estimation and Testing. Econometrica, 55, 251-276.

Fama, E. F., \& Schwert, G. (1977). Asset returns and inflation. Journal of Financial Economics, 5(2), 115-146.

Forgha, G., Serge, T., \& Ajong, N. (2018). Effects of Lending Relationship on the Interest Rates of Commercial Banks in Cameroon. Asian Journal of Economic Modelling, 6(2), 208-219.

Haseeb, M., Abidin, I. S. Z., Hye, Q. M. A., \& Hartani, N. H. (2018). The Impact of Renewable Energy on Economic Well-Being of Malaysia: Fresh Evidence from Auto Regressive Distributed Lag Bound Testing Approach. International Journal of Energy Economics and Policy, 9(1), 269-275.

Hashemzadeh, N., \& Taylor, P. (1988). Stock Prices, Money Supply and Interest Rates (The Question of Causality). Journal of Applied Economics, 20, 1603-1611.

Hussain, H. I., Salem, M. A., Rashid, A. Z. A., \& Kamarudin, F. (2019). Environmental Impact of Sectoral Energy Consumption on Economic Growth in Malaysia: Evidence from ARDL Bound Testing Approach. Ekoloji, 28(107), 199-210.

Le, H. T. (2015). Measuring the Stance of Monetary Policy in Vietnam: A Structural VAR Analysis. Asian Journal of Economics and Empirical Research, 2(1), 8-22.

Mahmoud, M., Somaye, S., \& Soraya, S. (2013). Fiscal Spending and Crowding Out Effect: A Comparison Between Developed and Developing Countries. Institutions and Economies, 5(1), 31-40.

Nguyen, P. C. (2018). The effectiveness of fiscal policy: contributions from institutions and external debts". Journal of Asian Business and Economic Studies, 25(1), 50-66.

Önder, M. (2018). Contribution of Plays and Toys to Children's Value Education. Asian Journal of Education and Training, 4(2), 146-149.

Onyinye, I., Jonathan, E., \& Emmanuel, O. (2018). Foreign Capital Inflows and Unemployment in Nigeria: A New Evidence from ARDL-Bounds Testing Approach. International Journal of Business, 5(6), 176-188.

Owusu-Antwi, G., Banerjee, R., \& Antwi, J. (2017). Interest Rate Spread on Bank Profitability: The Case of Ghanaian Banks. Journal of Accounting, Business and Finance Research, 1(1), 34-45.

Ozkurt, B., \& Alpay, C. B. (2018). Investigation of Proactive Personality Characteristics of the Students of High School of Physical Education and Sports through Various Variables. Asian Journal of Education and Training, 4(2), 150-155.

Özmaden, M., Soter, F., \& Özmaden, H. (2018). The Physical Education and Sport Studies in the Framework of Social Demands-Institutional Structuring and Teacher Training the Developments before and during Turkey Training Community Alliance Period (1922-1936). Asian Journal of Education and Training, 4(3), 170-175.

Patnaik, D., \& Pillai, A. (2017). Responsiveness of the Indian Tax System: A Time Series Analysis from 1990 to 2010. Economy, 4(1), 1-6.

Pesaran, M. H., Shin, Y., \& Smith R. J. (2000). Structural analysis of vector error correction models with exogenous I(1) variables. Journal of Econometrics, 97, 293-343.

Pesaran, M., \& Shin, Y. (1999). An Autoregressive Distributed Lag Modelling Approach to Cointegration.Econometrics and Economic Theory in the 20th Century: The Ragnar Frisch centennial Symposium. Edited by Strom, S., Cambridge University Press.

Pierson, G. (1968). The Effect of Economic Policy on the Term Structure of Interest Rates. Harvard University Press.

Sanusi, K. A., Meyer, D., \& Ślusarczyk, B. (2017). The relationship between changes in inflation and financial development. Polish Journal of Management Studies, 16(2), 253-265.

Siegal, J. J. (1994). Stock for The long Run, pp. 204-205. McGraw-Hill Education.

Sweis, K. M. H., \& Sabri, T. B. H. (2016). The Effect of Public Debt on Domestic Product and Unemployment (An Empirical Study on the Palestinian Economy). International Journal of Business, Economics and Management, 3(10), 133-143. 